\title{
Physicochemical and nutraceutical characterization of sirimbache fruit (Gaultheria glomerata (Cav.) Sleumer)
}

\author{
Mario Sergio Espinoza Aguilar ${ }^{1}$; Elvia Mercedes Gómez Villacorta ${ }^{1}$; Sonia Quispe \\ Contreras $^{2}$; Jesús A. Sánchez-González ${ }^{1, *}$; Jackeline Marilyn León-Vargas ${ }^{3}$ \\ ${ }^{I}$ Escuela de Ingeniería Agroindustrial, Facultad de Ciencias Agropecuarias (Universidad Nacional de Trujillo) Av. Juan \\ Pablo II s/n, Ciudad Universitaria, Trujillo, Peru. \\ 2 Fe y Alegría 57-CEFOP Cajamarca U.O. Celendín, Cajamarca, Peru. \\ ${ }^{3}$ School of Agroindustrial Engineering. Universidad Privada del Norte (UPN). Av. Del Ejército 920, Trujillo, Peru.
}

Received March 17, 2017. Accepted October 26, 2017.

\begin{abstract}
The consumption of vegetables with the greatest nutraceutical potential, especially those with high levels of antioxidants such as anthocyanin and phenolic compounds, has become popular among health conscious consumers. The aim of this research was to determine the nutraceutical potential of sirimbache fruits (Gaultheria glomerata (Cav.) Sleumer). Characterization of the berries resulted in the following: $11.4{ }^{\circ} \mathrm{Brix}, 3.25 \mathrm{pH}, 0.35 \%$ acidity, $83.74 \%$ moisture, $0.16 \%$ ash, monomeric anthocyanins (112.88 mg cyanidin 3-glucoside / $100 \mathrm{~g}$ of sample), total phenolic compounds (344.37 mg of gallic acid / $100 \mathrm{~g}$ of sample) and vitamin C (13.87 mg ascorbic acid/ $100 \mathrm{~g}$ of sample). These values indicate that sirimbache is a nutraceutical food of great interest. Therefore, the expansion of sirimbache to health conscious markets may be feasible. Such expansion is of great importance for rural agribusiness, as it could promote the development of new agroindustrial projects in the province of Celendin and other Andean areas of Peru.
\end{abstract}

Keywords: sirimbache; anthocyanins; phenolic compounds; berries; nutraceuticals.

\section{Introduction}

Nutraceuticals foods have received great attention in the last few years, especially those with a high content of antioxidants, which have been linked to reductions in cardiovascular disease, cancer, neurodegenerative diseases, inflammation, aging and problems caused by the presence of free radicals (Lobo et al., 2010; Rahman, 2007). Many studies have linked the incidence of different types of cancer to the lower intake of antioxidants (Pham-Huy et al., 2008). Antioxidants act as an electron donor, playing an important role in neutralizing free radicals by ending electron theft chain reactions (Ki and Hyong, 2006). Although several types of antioxidants exist, including anthocyanins and other phenolic

* Corresponding author

E-mail: jsanchezg@unitru.edu.pe (J. Sánchez-González). compounds, those present in fruits and vegetables have received the most attention (Pandey and Rizvi, 2009; Tsao, 2010).

Berries are considered nutraceutical foods because they are an important source of phytochemicals, among which are phenolic compounds (flavonoids, anthocyanins, phenolic acids and stilbenes). There are also reports that corroborate the biological activity of these phenols, including: antioxidant activity, anti-inflammatory and anticancer properties (Habauzit and Morand, 2012).

Natural phenolic compounds are secondary metabolites and are an important class of antioxidants found in all plants, with high concentrations often found in vegetables and fruits. An important role of phenolic

(C) 2017 All rights reserved. DOI: $10.17268 /$ sci.agropecu.2017.04.12 
compounds is to protect organisms against oxidative stress induced by free radical species (Cho et al., 2004).

Anthocyanins constitute an important part of phenolic compounds and are responsible for the colors of many fruits and flowers observed in nature (Oh et al., 2008). They are typically found in plant products such as purple corn, purple cabbage, red grape, mulberry, elderberry, purple sweet-corn, blueberry, and strawberry among others (Skrovankova et al., 2015). Various investigations have focused on the health benefits of these pigments, primarily a result of their antioxidant activity (Camire et al., 2002; Hou, 2003). Anthocyanins and anthocyanin extracts from plant material can provide various health benefits, including DNA protection (Lazzé et al., 2003; RamirezTortosa et al., 2001).

In Peru, there is a great variety of fruits, largely unknown to external markets, that can serve as a source of antioxidants (Repo and Encina, 2008). These native fruits are important sources of nutrients, such as vitamins (vitamin $\mathrm{C}$ and beta carotene) and minerals (phosphorus and potassium) (Repo and Encina, 2008). Among these is the sirimbache fruit, which is the popular name of the species Gaultheria Glomerata in the Celendin province (Cajamarca, norther of Peru). Cultivation of sirimbache has developed extensively with the shrubs used as fences of the cultivated lands, with the berries are marketed in various presentations at craft fairs and local markets. The Experimental Vocational Training Center (CEFOP) located in the Celendin province is one of the few in Peru that has developed agroindustrial products with marketing possibilities based on sirimbache. Based on the excellent results from the work conducted at CEFOP, it is possible that the crop will increase cultivation and application due to new entrepreneurship.

For this reason, this work aims to provide a physicochemical characterization of the sirimbache fruit, as well as to determine the content of compounds with important nutraceutical potential, mainly anthocyanins, total phenolic and vitamin $\mathrm{C}$.

\section{Material and methods}

\section{Plant Material}

Sirimbache, originating from Celendin province, Department of Cajamarca, Northern of Peru, was harvested by group or researcher in summer of 2016. The scientific denomination (figure 1) was made for Herbarium Truxillense (HUT) from Universidad Nacional de Trujillo as it follows:

- Popular name: Sirimbache

- Family: Ericaceae

- Scientific name: Gaultheria glomerata (Cav.) Sleumer

Berries were selected according to ripeness and size and then washed with potable water to separate the foreign materials and dust residues as well as berries subject to mechanical damage. After washing, the Sirimbache fruits were dehydrated and analyzed.

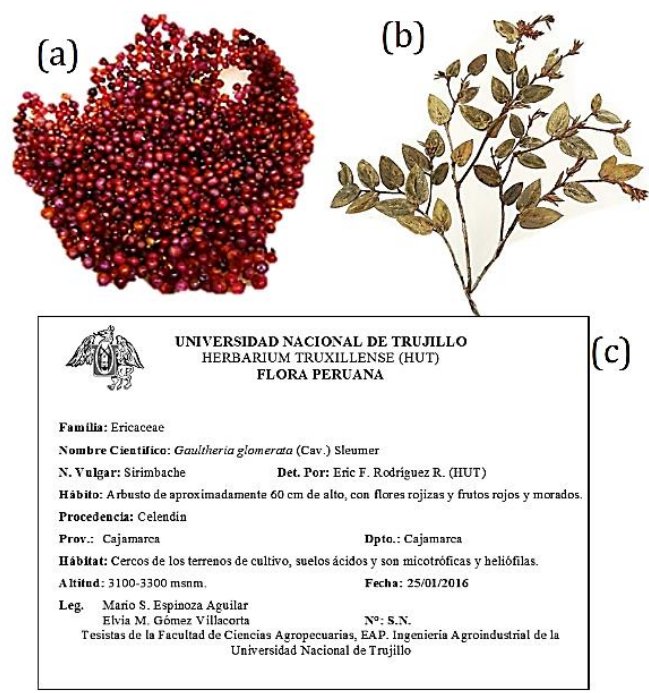

Figure 1. The Sirimbache: (a) Fruits. (b) Bush. (c) Identification file -HUT.

\section{Physicochemical analysis \\ Soluble solids and pH}

Soluble solids were determined using a digital refractometer (PAL-1 BLT/i, Atago, USA) at $20^{\circ} \mathrm{C}$, with the results expressed as Brix degrees. The $\mathrm{pH}$ was determined by potentiometric measurement using a $\mathrm{pH}$ meter (HI 2210, Hanna Instruments, Spain) according to IFU (2001) methods. 


\section{Titratable acidity and ripeness index}

The acidity of the samples was measured using $10.0 \mathrm{~g}$ of homogenized fruit diluted in $250 \mathrm{~mL}$ of distilled water, and then filtered. Aliquots of $50 \mathrm{~mL}$ were transferred to Erlenmeyer flasks and then titrated using $0.1 \mathrm{~N} \mathrm{NaOH}$ to a $\mathrm{pH}$ endpoint of 8.10 as given by a phenolphthalein (1\%) indicator, and confirmed with a $\mathrm{pH}$ meter (HI 2210, Hanna Instruments, Spain).

The total acidity was expressed as mg citric acid / g sample, and was calculated using the expression: Acidity $=\left[\left(\mathrm{NaOH} \times \mathrm{V}_{1} \times\right.\right.$ EQ acid) / $\left.\left(V_{2}\right)\right]$, where $V_{1}$ is the volume of $\mathrm{NaOH}, \mathrm{V}_{2}$ is the volume of the sample, and EQ is the equivalent of the citric acid (64 mg/equivalent) (Cerdán-Calero et al., 2013).

The ripeness index was calculated as the average of the soluble solids in relation to the acid ( ${ }^{\circ}$ Brix/acidity) (Amorós et al., 2003; Pinillos et al., 2011).

\section{Moisture content and ash}

The moisture content of the samples was determined by drying $10 \mathrm{~g}$ of sirimbache at $105{ }^{\circ} \mathrm{C}$ (AOAC, 2000) in an oven (UNB 400, Memmert, Germany) until finding insignificant changes for 3 hours.

The ash was determined by incinerating approximately $3 \mathrm{~g}$ of Sirimbache berries at $550{ }^{\circ} \mathrm{C}-600{ }^{\circ} \mathrm{C}$ inside a muffle furnace (MF 7, Fravill, Peru) for 2 hours.

\section{Analysis of nutraceutical compounds Total monomeric anthocyanins (TMA)}

$10 \mathrm{~g}$ of crushed Sirimbache was added to 40 $\mathrm{mL}$ of alcohol-water solutions $(80: 20 \mathrm{v} / \mathrm{v})$. The extract was kept cool overnight and filtered the next day using S \& S 520 (Schleicher \& Schuell - Whatman filter paper grade 520, Maidstone, United Kingdom) (Wicklund et al., 2005).

The TMA was quantified using a $\mathrm{pH}-$ differential method according to Giusti's method (Giusti and Wrolstad, 2001); using hydrochloric acid / potassium chloride buffer $(0.025 \mathrm{M}, \mathrm{pH} 1.0)$ and sodium acetate buffer $(0.4 \mathrm{M}, \mathrm{pH} 4.5)$. Briefly, 0.2 $\mathrm{mL}$ of the filtrate was mixed with $1.8 \mathrm{~mL}$ of one of the buffer solutions and the absorbance of each dilution was measured at $\lambda=515 \mathrm{~nm}$ and $\lambda=700 \mathrm{~nm}$. A UNICO ${ }^{\circledR}$ 4802 UV-vis double-beam spectrophotometer was used to measure absorption spectra of the system.

The absorbance (A) of the diluted samples was calculated using the following formula: $A=\left(A_{515}-A_{700}\right) p H 1.0-\left(A_{515}-\right.$ $\left.A_{700}\right) p H 4.5$

Where $\mathrm{A}$ is the absorbance of the diluted samples. $A_{515}$ is the absorbance measured at $\lambda_{515}$, and $A_{700}$ is the measured absorbance at $\lambda_{700}$.

The total monomeric anthocyanins content was expressed as cyanidin-3-O-glucoside per $g$ of fruit and was calculated by:

$\operatorname{TMA}\left(\frac{\mathrm{mg}}{100 \mathrm{~g}}\right)=\frac{\left(\mathrm{A} * M_{W} \times \mathrm{DF} \times 100\right)}{M_{A} * L}$

Where:

$\mathrm{M}_{\mathrm{W}}$ is the molecular weight $(449.2 \mathrm{~g} / \mathrm{mol})$; $\mathrm{DF}$ is the dilution factor $(50) ; \mathrm{M}_{\mathrm{A}}$ is the extinction coefficient $26.900 \mathrm{~L} /\left(\mathrm{cm}^{*} \mathrm{~mol}\right)$; $\mathrm{L}=$ path length $(1 \mathrm{~cm})$.

\section{Total phenolics compounds}

Total phenols were determined according to (Espinoza et al., 2016; Holtung et al., 2011; Viuda-Martos et al., 2010) with some modifications. The analyses were performed by visible spectrophotometry (4802 UV-vis, UNICO ${ }^{\circledR}$, USA) after reaction with the Folin-Ciocalteu reagent (Merck Millipore®, Darmstadt-Germany). Ethyl alcohol $\left(80^{\circ} \mathrm{v} / \mathrm{v}\right)$ was added to $2.0 \mathrm{~g}$ of crushed sirimbache and filled up to 10 $\mathrm{mL}$ in a centrifuge tube. This mixture was stirred and centrifuged at $4200 \mathrm{rpm}$ for 15 minutes then filtered using $\mathrm{S} \& \mathrm{~S} 520$ (Schleicher \& Schuell - Whatman filter paper grade 520, Maidstone, United Kingdom).

The extracts from the samples $(20 \mu \mathrm{L})$ were added to test tubes with $1580 \mu \mathrm{L}$ of distilled water and $100 \mu \mathrm{L}$ of Folin-Ciocalteu reagent. This mixture was kept in the dark at room temperature for 20 minutes and then transferred into a $40{ }^{\circ} \mathrm{C}$ water bath (WNB 14, Memmert, Germany) with 300 $\mu \mathrm{L}$ addition of $20 \%$ sodium carbonate solution (w/v) for $15 \mathrm{~min}$.

The absorbance of all samples was measured at $760 \mathrm{~nm}$ after incubation at 50 
${ }^{\circ} \mathrm{C}$ for 10 minutes in an oven (UNB 400, Memmert, Germany). The results were calculated using a calibration curve obtained from a standard of gallic acid (Sigma-Aldrich $^{\circledR}$, Spain) and expressed as $\mathrm{mg}$ of gallic acid / $100 \mathrm{~g}$ of sirimbache.

\section{Content of ascorbic acid}

The ascorbic acid content was assessed by the 2, 6-dichloroindophenol titrimetric method, according to Varming et al. (2013). Briefly, $5.0 \mathrm{~g}$ of crushed fruit was diluted with $50 \mathrm{~mL}$ of oxalic acid solution $(1 \mathrm{~g} / 100$ $\mathrm{mL}$ ) (Merck, Darmstadt, Germany) and then filtered using S \& S 520 (Schleicher \& Schuell - Whatman filter paper grade 520, Maidstone, United Kingdom) and transferred to a volumetric flask. After preparing the samples, aliquots of $10 \mathrm{~mL}$ were transferred to Erlenmeyer flasks, a further $50 \mathrm{~mL}$ of oxalic acid solution was added, and the solution was then mixed and titrated with 2, 6-dichloroindophenol solution $(0.02$ $\mathrm{g} / 100 \mathrm{~mL}$ ) (Sigma-Aldrich ${ }^{\circledR}$, Denmark). The final point was considered when the solution had a pink color for $15 \mathrm{~s}$. The calibration of the 2, 6-dichlorophenolindophenol solution was performed with $0.05 \%$ ascorbic acid solution (Merck, Darmstadt, Germany) and expressed as milligrams of ascorbic acid / $100 \mathrm{~g}$ of sirimbache. All quantifications were conducted in triplicate.

\section{Results and discussion}

\section{Sirimbache fruit's characterization Physicochemical analysis}

The values of the initial parameters, as well as the physicochemical and functional characteristics of the sirimbache fruit, are shown in Table 1. A comparison of data from sirimbache and other berries previously studied is shown in Table 2, in order to provide perspective on the physicochemical and functional characteristics of better-studied berries in relation to sirimbache.

The pulp of the sirimbache had a soluble solids content between 10 and $15{ }^{\circ}$ Brix, which is equivalent to values of other berries as shown in Table 2. The $\mathrm{pH}$ of the pulp is consistent with previous studies, which found $\mathrm{pH}$ values between 3.0 and 3.4 for wild fruits (Arteaga and Arteaga, 2016). In addition, these values are consistent with those of other berries, including blackberries and strawberries where $\mathrm{pH}$ of 3.23 and 3.4, respectively were found (Hassimotto et al., 2008). Because the main organic acid present in the genus Vaccinium is citric acid (Kalt and McDonald, 1996), the acidity of the Sirimbache was expressed as citric acid, in order to simplify comparison with the other fruits.

Table 1

The physicochemical and functional composition of Sirimbache (g/100 g of fruit)

\begin{tabular}{|c|c|c|}
\hline \multirow{2}{*}{ Composition } & \multicolumn{2}{|c|}{ Sirimbache } \\
\hline & w.b X $\pm S$ & d.b $\mathrm{X} \pm \mathrm{S}$ \\
\hline Soluble solids ${ }^{(a)}$ & $11.43 \pm 0.15$ & ND \\
\hline $\mathrm{pH}$ & $3.25 \pm 0.05$ & NDV \\
\hline Titratable acidity ${ }^{(b)}$ & $0.346 \pm 0.005$ & NDV \\
\hline Ripeness index ${ }^{(\mathrm{c})}$ & $33.08 \pm 0.44$ & NDV \\
\hline Moisture content (\%) & $83.74 \pm 0.03$ & NDV \\
\hline Ash (\%) & $0.162 \pm 0.001$ & $0.996 \pm 0.006$ \\
\hline Total monomeric anthocyanins (d) & $112.88 \pm 0.72$ & $694.20 \pm 0.09$ \\
\hline Total phenolics (e) & $344.37 \pm 0.06$ & $2117.91 \pm 0.03$ \\
\hline Vitamin $\mathrm{C}^{(\mathrm{f})}$ & $13.87 \pm 0.14$ & $85.20 \pm 0.83$ \\
\hline
\end{tabular}

w.b: wet basis; d.b: dry basis; X: average; S: standard deviation. NDV: No determinate value.

(a) ${ }^{\circ}$ Brix at $20^{\circ} \mathrm{C}$.

(b) $\mathrm{mg}$ citric acid/g of sample.

(c) Ratio ${ }^{\circ}$ Brix/titrabable acidity.

(d) mg cyanidin 3-glucoside / $100 \mathrm{~g}$ sample.

(e) $\mathrm{mg}$ gallic acid / $100 \mathrm{~g}$ sample.

(f) $\mathrm{mg}$ of ascorbic acid / $100 \mathrm{~g}$ sample. 
Table 2

Comparison of sirimbache composition with other berries

\begin{tabular}{|c|c|c|c|c|c|c|}
\hline Composition & Sirimbache & Cranberry & $\begin{array}{c}\text { Blackberry } \\
\text { (Andean) }\end{array}$ & Strawberry & Goldenberry & $\begin{array}{c}\text { Blackberry } \\
\text { (Chester) }\end{array}$ \\
\hline Soluble solids ${ }^{(\mathrm{a})}$ & 11.43 & --- & $9.00^{(5)}$ & $11.06^{(11)}$ & $14.06^{(15)}$ & $12.25^{(19)}$ \\
\hline $\mathrm{pH}$ & 3.25 & $3.2^{(2)}$ & $2.88^{(6)}$ & $3.48^{(11)}$ & $3.58^{(16)}$ & $3.23^{(19)}$ \\
\hline Titratable acidity ${ }^{(b)}$ & 0.346 & $0.86^{(2)}$ & $0.87^{(7)}$ & $0.93^{(11)}$ & $1.59^{(16)}$ & $0.93^{(20)}$ \\
\hline Moisture content (\%) & 83.74 & $87.3^{(1)}$ & $88.76^{(6)}$ & $89.3^{(12)}$ & $81.3^{(17)}$ & $82.98^{(20)}$ \\
\hline Ash $(\%)$ & 0.16 & $0.21^{(3)}$ & $0.4^{(8)}$ & $0.69^{(13)}$ & $1.17^{(16)}$ & $0.42^{(20)}$ \\
\hline $\begin{array}{l}\text { Total monomeric } \\
\text { anthocyanins (d) }\end{array}$ & 112.88 & $259.5^{(4)}$ & $270^{(9)}$ & $450.10^{(11)}$ & --- & $109.07^{(20)}$ \\
\hline Total phenols ${ }^{(\mathrm{e})}$ & 344.37 & $519.5^{(4)}$ & $118^{(9)}$ & $147.80^{(14)}$ & $58.6^{(16)}$ & $400.67^{(20)}$ \\
\hline Vitamin $\mathrm{C}^{(\mathrm{f})}$ & 13.87 & $13^{(3)}$ & $10^{(10)}$ & $0.27^{(13)}$ & $43.3^{(18)}$ & $14.37^{(20)}$ \\
\hline \multicolumn{2}{|c|}{$\begin{array}{l}\text { (a) }{ }^{\circ} \text { Brix a } 20{ }^{\circ} \mathrm{C} \text {. } \\
\text { (b) } \mathrm{mg} \text { citric acid/g of sample. } \\
\text { (c) Ratio }{ }^{\circ} \text { Brix / titrable acidity. } \\
\text { (d) } \mathrm{mg} \text { cyanidin 3-glucoside / } 100 \mathrm{~g} \text { sample. } \\
\text { (e) } \mathrm{mg} \text { gallic acid / } 100 \mathrm{~g} \text { sample. } \\
\text { (f) } \mathrm{mg} \text { of ascorbic acid / } 100 \mathrm{~g} \text { sample. } \\
\text { (1) Garrido and Pérez-Urria (2014). } \\
\text { (2) Sapers } \text { et al. }(1984) \text {. } \\
\text { (3) Prior } \text { t al. }(1998) \text {. }\end{array}$} & \multicolumn{2}{|c|}{$\begin{array}{l}\text { (4) Moyer et al. }(2002) \text {. } \\
\text { (5) Tosun et al. }(2008) \text {. } \\
\text { (6) Ayala et al. }(2013) . \\
\text { (7) Kopjar et al. }(2009) . \\
\text { (8) Carmona et al. }(1996) \text {. } \\
\text { (9) Kuskoski } \text { et al. }(2004) . \\
\text { (10) Velazco and Vega (2003). } \\
\text { (11) Yorgey et al. }(1995) . \\
\text { (12) Sellappan } \text { et al. }(2002) .\end{array}$} & \multicolumn{3}{|c|}{$\begin{array}{l}{ }^{(13)} \text { Martínez-Soto } \text { et al. (2008). } \\
{ }^{(14)} \text { Sun } \text { et al. }(2002) . \\
{ }^{(15)} \text { Rossi } \text { et al. }(2012) . \\
{ }^{(16)} \text { Guevara-Pérez and Málaga-Barreda (2013). } \\
{ }^{(17)} \text { Yildiz } \text { et al. }(2015) . \\
{ }^{(18)} \text { Repo and Encina (2008). } \\
{ }^{(19)} \text { Hassimotto } \text { et al. }(2008) . \\
\text { (20) Valencia and Guevara-Pérez (2013). }\end{array}$} \\
\hline
\end{tabular}

As shown in Table 2, the measured moisture content of the berries examined here is relatively narrow and ranges from $81.3 \%$ to $83.74 \%$ for Goldenberry and sirimbache, respectively. The ash content of sirimbache was found to be $0.162 \pm 0.001 \%$ on the wet basis, values very close to cranberry. In addition, other studies suggest that the ash content of sirimbache ranked between 0.15 to $0.31 \%$ (Hassimotto et al., 2008) which agrees with the value found for sirimbache $(0.162 \%)$.

\section{Nutraceutical compounds analysis Total monomeric anthocyanins}

Anthocyanins are the most important group of water-soluble pigments in plants. More than 550 unique anthocyanin compounds have been reported, which is distributed mainly in flowers, pulp and peel fruits and vegetables (Kong et al., 2003; Skrovankova et al., 2015). Anthocyanins are also responsible for the orange, red, purple and blue colors. Their chemical proportions depend on many factors such as the $\mathrm{pH}$ of the medium, temperature, among others (Peña, 2006). The total monomeric anthocyanins value was $112.88 \pm 0.72 \mathrm{mg}$ cyanidin 3 glucoside / $100 \mathrm{~g}$ of fresh extract. This value is similar to blackberries (Hassimotto et al., 2008), but substantially lower than values for other berries (Table 2).

\section{Total phenolics}

Phenolic compounds can play several roles as antioxidants, and also have key sensory attributes (bitterness and astringency), which is why they have attracted the attention of many researchers (Hamauzu et al., 2006). The total phenol content in Sirimbache was $344.37 \pm 0.06 \mathrm{mg}$ gallic acid /100 g fresh weight, more than $154 \mathrm{mg}$ gallic acid equivalent / $100 \mathrm{~g}$ (w.b) greater than that for Goldenberries (Repo and Encina, 2008), indicating that the sirimbache fruit has an important content of phenolic compounds. Many authors have identified that the primary causes of differences in anthocyanin and total phenol content between different species of berries are factors such as surface to volume ratio of the species, area of cultivation, environmental conditions before harvesting, genetic differences, differences in maturation and different degrees of ripeness at the time of harvest (Taruscio et al., 2004; Zadernowski et al., 2005). Differences in phenolic compounds could also be related to different handling procedures during postharvest storage (Kalt and McDonald, 1996).

\section{Vitamin C}

Is a potent antioxidant. Ascorbic acid has the ability to remove different reactive oxygen species, maintain $\alpha$-tocopherol in 
the reduced state, act as a cofactor by maintaining the activity of a number of enzymes (by keeping the metal ions in the reduced state). Evidence also suggests that it can serve as a substrate for oxalate and tartrate biosynthesis, and has a role in stress resistance (Klein and Kurilich, 2000). Sirimbache was found to contain $13.87 \pm$ $0.14 \mathrm{mg}$ of ascorbic acid / $100 \mathrm{~g}$ sample. This value is substantially lower than has been identified for goldenberries, $43.3 \pm 0.5$ mg ascorbic acid / $100 \mathrm{~g}$ (Repo and Encina, 2008), but is still comparable to Chester variety blackberries, $14.3 \mathrm{mg}$ ascorbic acid / $100 \mathrm{~g}$ sample; Andean variety blackberries, $10 \mathrm{mg}$ ascorbic acid / $100 \mathrm{~g}$ sample (Pantelidis et al., 2007; Velazco and Vega, 2003); and cranberries.

\section{Conclusions}

The physicochemical composition on a wet basis of sirimbache fruits was examined. The content of nutraceutical compounds in sirimbache fruit was also determined. These results indicate that sirimbache is largely comparable to a variety of berries, including blackberries, strawberries, and goldenberries. From this, sirimbache fruit can be considered a functional food of a great interest for the food agro-industry due to its high content of total monomeric anthocyanins, phenolics and vitamin C. Because of this, additional projects to promote the development of sirimbache as an agroindustrial crop are warranted.

\section{References}

Amorós, A.; Zapata, P.; Pretel, M.; Botella, M.; Serrano., M. 2003. Physico-chemical and physiological changes during fruit development and ripening of five loquat (Eriobotrya japonica Lindl.) cultivars. Revista de Agaroquimica y Tecnologia de Alimentos 9(1): 43-51.

AOAC. 2000. Official method of analysis of AOAC International (17th ed.). USA.

Arteaga, A.; Arteaga, H. 2016. Optimización de la capacidad antioxidante, contenido de antocianinas y capacidad de rehidratación en polvo de arándano (Vaccinium corymbosum) microencapsulado con mezclas de hidrocoloides. Scientia Agropecuaria 7: 191-200.

Ayala, L.; Valenzuela, C.; Bohórquez, Y. 2013. Physicochemical characterization of Castilla Blackberry (Rubus glaucus Benth) in six maturity states. Biotecnología en el Sector Agropecuario y Agroindustrial 11: 10-18.

Camire, M.; Chaovanalikit, A.; Dougherty, M.; Briggs, J. 2002. Blueberry and grape anthocyanins as breakfast cereal colorants. Journal of Food Science 1: 438-441.

Carmona, M.; Aguirre, G.; Echeverri, M.; Giraldo, J.; Gutiérrez, A.; Tovar, W.; Varón., S. 1996. Caracterización fisicoquímica de seis materiales de mora (Rubus glaucus Benth.) producidas en la ciudad de Manizales. Memorias 1er Seminario Nacional de Frutales de Clima Frío Moderado. Manizales 55-60.

Caruso, F.; Ramsdell, D. 1995. Compendium of blueberry and cranberry diseases. Amer Phytopathological Society, USA.

Cerdán-Calero, M.; Izquierdo, L.; Sentandreu., E. 2013. Valencia Late orange juice preserved by pulp reduction and high pressure homogenization: Sensory quality and gas chromatography-mass spectrometry analysis of volatiles. LWT - Food Science and Technology 51: 476-483.

Cho, M.; Howard, L.; Prior, R.; Clark., J. 2004. Flavonoid glycosides and antioxidant capacity of various blackberry, blueberry and red grape genotypes determined by high-performance liquid chromatography/mass spectrometry. Journal of the Science of Food and Agriculture 84: 1771-1782.

Espinoza, M.; Gómez, E.; Aguilar, J.; Cabanillas, J.; Santa Cruz, M.; Rodríguez, I.; Ríos, R.; Zuta, I.; Siche., R. 2016. Impacto térmico del secado por Ventana Refractante ${ }^{\mathrm{TM}}$ sobre los metabolitos antioxidantes de la cáscara del membrillo (Cydonia oblonga L.). Agroindustrial Science 5: 143-151.

Garrido, M.; Pérez-Urria, E. 2014. Arándano rojo I (Vaccinium macrocarpon Ait.). Reduca (Biología). Serie Botánica 7: 100-112.

Giusti, M.; Wrolstad., R.. 2001. Characterization and Measurement of Anthocyanins by UV-visible Spectroscopy. In Handbook of Food Analytical Chemistry (Vol. 2-2, pp. 19-31).

Guevara-Pérez; A.; Málaga-Barreda, R. 2013. Determinación de los parámetros de proceso y caracterización del puré de aguaymanto. Ingeniería Industrial 31: 167-195.

Habauzit, V.; Morand, C. 2012. Evidence for a protective effect of polyphenols-containing foods on cardiovascular health: an update for clinicians. Therapeutic Advances in Chronic Disease 3: 87-106

Hamauzu, Y.; Inno, T.; Kume, C.; Irie, M.; Hiramatsu, K. 2006. Antioxidant and antiulcerative properties of phenolics from Chinese quince, quince, and apple fruits. Journal of Agricultural and Food Chemistry 54: 765772.

Hassimotto, N.; Da Mota, R.; Cordenunsi, B.; Lajolo, F. 2008. Physico-chemical characterization and bioactive compounds of blackberry fruits (Rubus $s p$.) grown in Brazil. Ciencia e Tecnologia de Alimentos 28: 702-708.

Holtung, L.; Grimmer, S.; Aaby, K. 2011. Effect of processing of black currant press-residue on polyphenol composition and cell proliferation. Journal of Agricultural and Food Chemistry 59: 3632-3640.

Hou, DX. 2003. Potential mechanisms of cancer chemoprevention by anthocyanins. Current Molecular Medicine 3: 149-159.

Kalt, W.; McDonald, J.. 1996. Chemical Composition of Lowbush Blueberry Cultivars. Journal of the American Society for Horticultural Science 121: 142-146.

$\mathrm{Ki}$, W.; Hyong, J. 2006. The roles of polyphenols in cancer chemoprevention. BioFactors 26: 105-121.

Klein, B.; Kurilich, A. 2000. Processing effects on dietary antioxidants from plant foods. HortScience 35: 580584.

Kong, J.; Chia, L.; Goh, N.; Chia, T.; Brouillard, R. 2003. Analysis and biological activities of anthocyanins. Phytochemistry 64: 923-933.

Kopjar, M.; Tiban, N.; Pilizota, V.; Babic., J. 2009. Stability 
of anthocyanins, phenols and free radical scavenging activity through sugar addition during frozen storage of blackberries. Journal of Food Processing and Preservation 33: 1-11.

Kuskoski, E.; Asuero, A.; García-Parilla, M.; Troncoso, A.; Fett., R. 2004. Actividad antioxidante de pigmentos antociánicos. Food Science and Technology (Campinas) 24: 691-693.

Lazzé, M.; Pizzala, R.; Savio, M.; Stivala, L.; Prosperi, E.; Bianchi, L. 2003. Anthocyanins protect against DNA damage induced by tert-butyl-hydroperoxide in rat smooth muscle and hepatoma cells. Mutation Research - Genetic Toxicology and Environmental Mutagenesis 535: 103-115.

Lobo, V.; Patil, A.; Phatak, A.; Chandra., N. 2010. Free radicals, antioxidants and functional foods: Impact on human health. Pharmacogn Rev 4: 118-126.

Martínez-Soto, G.; Mercado-Flores, J.; López-Orozco, M.; Prieto-Velásquez., B. 2008. Propiedades fisicoquímicas de seis variedades de fresa (Fragaria ananassa) que se cultivan en Guanajuato. Revista Salud Pública y Nutrición (8) Special Issue. Available from http://www.respyn.uanl.mx/especiales/2008/ee-082008/index.html

Moyer, R.; Hummer, K.; Finn, C.; Frei, B.; Wrolstad, R. 2002. Anthocyanins, phenolics, and antioxidant capacity in diverse small fruits: Vaccinium, Rubus, and Ribes. Journal of Agricultural and Food Chemistry 50: 519-525.

Oh, Y.; Lee, J.; Yoon, S.; Oh, C.; Choi, D.; Choe, E.; Jung., M. 2008. Characterization and quantification of anthocyanins in grape juices obtained from the grapes cultivated in Korea by HPLC/DAD, HPLC/MS, and HPLC/MS/MS. Journal of Food Science 73: 378-389.

Pandey, K.; Rizvi, S. 2009. Plant polyphenols as dietary antioxidants in human health and disease. Oxidative Medicine and Cellular Longevity 2: 270-278.

Pantelidis, G.; Vasilakakis, M.; Manganaris, G.; Diamantidis, G. 2007. Antioxidant capacity, phenol, anthocyanin and ascorbic acid contents in raspberries, blackberries, red currants, gooseberries and Cornelian cherries. Food Chemistry 102: 777-783.

Peña, A. 2006. El color de los vinos. Grupo de Investigación Enológica de la Universidad de Chile, Vendimia, 2426. Available from: http://www.gie.uchile.cl/publicaciones/index.htm

Pham-Huy, L.; He, H.; Pham-Huy, C. 2008. Free radicals, antioxidants in disease and health. International Journal of Biomedical Science 4: 89-96.

Pinillos, V.; Hueso, J.; Marcon, J.; Cuevas., J. 2011. Changes in fruit maturity indices along the harvest season in "Algerie" loquat. Scientia Horticulturae 129: 769-776.

Prior, R.; Cao, G.; Martin, A.; Sofic, E.; McEwen, J.; O’Brien, C.; Lischner, N. 1998. Antioxidant capacity as influenced by total phenolic and anthocyanin content, maturity, and variety of Vaccinium species. Journal of Agricultural and Food Chemistry 46: 2686-2693.

Rahman, K. 2007. Studies on free radicals, antioxidants, and co-factors. Clinical Interventions in Aging 2: 219-236.

Ramirez-Tortosa; C.; Andersen, Ø.; Gardner, P.; Morrice, P.; Wood, S.; Duthie, S., Collins, A.; Duthie., G. 2001. Anthocyanin-rich extract decreases indices of lipid peroxidation and DNA damage in vitamin E-depleted rats. Free Radical Biology and Medicine 9: 1033-1037.

Repo, R.; Encina, C. 2008. Determination of Antioxidant Capacity and Bioactive Compounds in Native Peruvian
Fruits. Revista de La Sociedad Química de Perú 2: 108_124

Rossi, D.; Pardo, F.; Reyes, D.; Tirado, R.; Urbina, E.; Vega, J. 2012. Efecto de la temperatura y sinergismo de sacarosa, sacarina y sugar light en la deshidratación osmótica de aguaymanto (Physalis peruviana). Agroindustrial Science 2: 100-109.

Sapers, G.; Burgher, A.; Phillips, J.; Jones, S. 1984. Color and composition of highbush blueberry cultivars. Journal of the American Society for Horticultural Science 109: 105-111.

Sellappan, S.; Akoh, C.; Krewer, G. 2002. Phenolic compounds and antioxidant capacity of Georgia-grown blueberries and blackberries. Journal of Agricultural and Food Chemistry 50: 2432-2438.

Skrovankova, S.; Sumczynski, D.; Mlcek, J.; Jurikova, T.; Sochor., J. 2015. Bioactive compounds and antioxidant activity in different types of berries. International Journal of Molecular Sciences 16: 24673-24706.

Valencia, C.; Guevara-Pérez, A. 2013. Elaboración de néctar de zarzamora (Rubus fructicosus L.). Scientia Agropecuaria 4: 101-109.

Sun, J.; Chu, Y.; Wu, X.; Liu, R. 2002. Actividades antioxidantes y antiproliferativas de algunas frutas. Journal of Agricultural and Food Chemistry 50: 7449 7454.

Taruscio; T.; Barney, D.; Exon., J. 2004. Content and profile of flavanoid and phenolic acid compounds in conjunction with the antioxidant capacity for a variety of northwest Vaccinium berries. Journal of Agricultural and Food Chemistry 52: 3169-3176.

Tosun, I.; Ustun, N.; Tekguler., B. 2008. Physical and chemical changes during ripening of blackberry fruits. Scientia Agricola 65: 87-90.

Tsao, R. 2010. Chemistry and biochemistry of dietary polyphenols. Nutrients 2: 1231-1246.

Velazco, E.; Vega., R. 2009. Estabilidad del ácido ascórbico en productos elaborados de camu camu (Myrciaria dubia)(HBK) Mc Vaugh. Centro de Promoción de la Biodiversidad Amazónica. Available from http://www.promamazonia.org.pe/wfr_Descarga.aspx? id $=+O e S r X x i V 0 T K M K V 5 E E Y E N w==\&$ tipo=SNrz4C Y7n79ZfATct19apg==

Viuda-Martos, M.; Navajas, Y.; Zapata, E.; FernandezLopez, J.; Perez-Alvarez, J. 2010. Antioxidant activity of essential oils of five spice plants widely used in a Mediterranean diet. Flavour and Fragrance Journal 25: 13-19.

Wicklund, T.; Rosenfeld, H.; Martinsen, B.; Sundfør, M.; Lea, P.; Bruun, T.; Blomhoff, R.; Haffner, K. 2005. Antioxidant capacity and colour of strawberry jam as influenced by cultivar and storage conditions. LWT Food Science and Technology 38: 387-391.

Yıldız, G.; İzli, N.; Ünal, H.; Uylaşer, V. 2015. Physical and chemical characteristics of goldenberry fruit (Physalis peruviana L.). Journal of Food Science Technology 52: 2320-2327.

Yorgey, B.; Farkas, D.; Finn, C. 1995. Evaluation of Processing Quality of Advanced Strawberry and Cranberry Breeding Selections. Research Progress Report. Oregon Strawberry Commission. Available from

http://www.mjsunderground.net/strawresreports/rep16/ yorge95a.htm\#redrasp

Zadernowski, R.; Naczk, M.; Nesterowicz, J. 2005. Phenolic acid profiles in some small berries. Journal of Agricultural and Food Chemistry 53: 2118-2124. 